\title{
Investigation of rainfall-induced shallow landslides on the northeastern rim of Aso caldera, Japan, in July 2012
}

\author{
Hufeng Yang ${ }^{1 *}$, Fawu Wang ${ }^{1}$, Vít Vilímek ${ }^{2}$, Kiminori Araiba ${ }^{3}$ and Shiho Asano ${ }^{4}$
}

\begin{abstract}
Background: High-intensity rainfall struck the Northern Kyushu area of Japan between 11 and 14 July 2012. This heavy rainfall triggered many shallow landslides, especially on the northeastern rim of Aso caldera, leading to significant loss of life and damage to many villages. One landslide site at Ichinomiya (Kumamoto Prefecture) was selected for detailed study. Field and laboratory investigations were conducted to identify the initiation mechanism of the shallow landslides during heavy rainfall.
\end{abstract}

Results: The thickness of the soil layer was determined using portable dynamic cone penetration tests. The soils became thinner (about $1 \mathrm{~m}$ ) from the upper to the lower slope. In-situ infiltration tests indicate that hydraulic conductivity of this thin soil layer is low. During heavy rainfall events, most rainfall will transform into surface runoff instead of infiltration. The results of consolidated-undrained triaxial compression tests show that the effective friction angle and cohesion of the soil are $36.9^{\circ}$ and $6.3 \mathrm{kPa}$, respectively. Soil behavior in response to increase in pore-water pressure was evaluated using a pore-water pressure controlled triaxial test.

Conclusions: The results indicate that the steep slopes on the northeastern rim of Aso caldera will remain stable under normal rainfall conditions, due to the high shear strength of the soil. The probable initiation mechanism for the shallow landslides on the northeastern rim of Aso caldera suggests that the initial failure process begins with toe erosion caused by surface runoff during heavy rainfall. Due to the loss of the resistance force at the toe of slope, the slope will reach a critical condition when pore-water pressure in the slope also increases.

\section{Background}

The Northern Kyushu area of Japan experienced high-intensity rainfall from 11 to 14 July, 2012. This heavy rainfall triggered many shallow landslides, especially on the northeastern rim of Aso caldera (Fig. 1). These shallow landslides, as the resource for debris flows, occurred on the upper slopes, at the inner rim of caldera. Trees growing along the gullies on the middle slopes were carried away by the debris flows. Many sabo dams (i.e. check dams) in the path of the debris flows were destroyed. The debris flows affected many villages and local settlers. The debris flows claimed 30 lives, with another two people remaining unaccounted for, and 13,263 houses were completely or partially damaged (Fire and Disaster Management

\footnotetext{
* Correspondence: yanghufeng@gmail.com

'Department of Geoscience, Shimane University, Matsue 690-8504, Japan Full list of author information is available at the end of the article
}

Agency, Japan 2012). Transport routes and large areas of farmland were also affected. The total property loss was estimated to be about 2 billion USD (JSCE 2013). Shallow landslides often occur in weathered debris or loose soil materials on steep slopes during heavy rainfall (Maharaj 1993; Zhu and Anderson 1998; Dai et al. 1999, 2004; Dai and Lee 2002; Capra et al. 2003; Yu et al. 2006, Dahal et al. 2009; Giannecchini et al. 2012; Yang et al. 2015; Wang et al. 2015). Annual rainfall in Kyushu is quite high, due to stagnation of wet fronts in the area during the rainy season, from May to July. Normally, few landslides occur during limited rainfall. However, during heavy rainfall events, shallow landslides and debris flows are commonly triggered around the rim of Aso caldera (Miyabuchi et al. 2004, 2007; Miyase 2012; Matsushi et al. 2013). It is obvious that heavy rainfall is the main triggering factor of these geo-disasters. Several studies have been carried out to examine the 


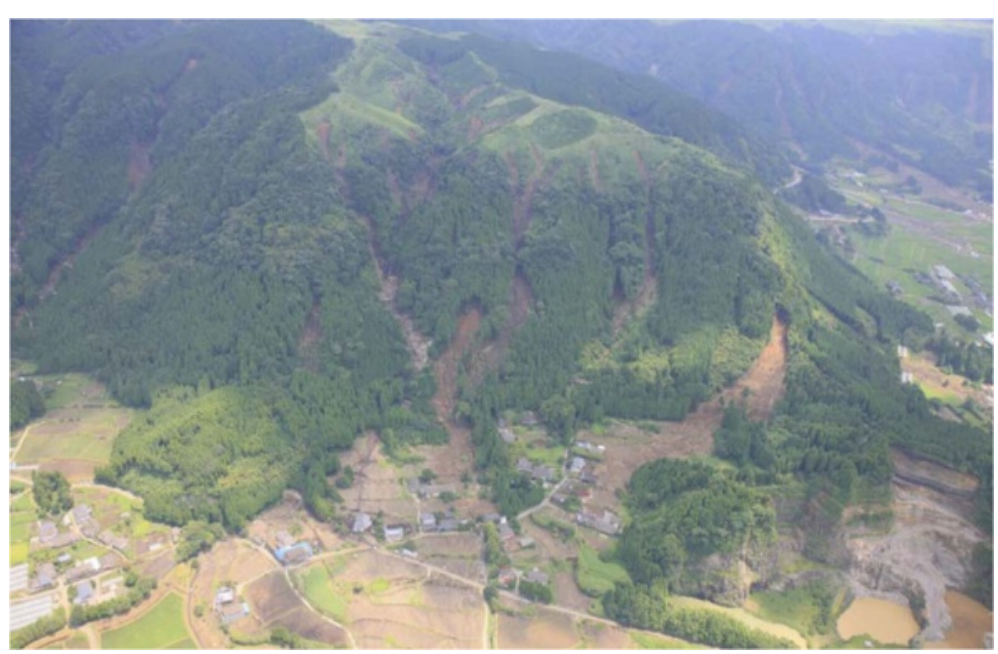

Fig. 1 Shallow landslides on the northeastern rim of Aso caldera (image courtesy of Kokusai Kogyo Co., Ltd, Japan)

factors contributing to the occurrence of shallow landslides in Kyushu. Paudel et al. (2003, 2008) and Miyabuchi et al. (2011) reported that the soils on the slopes consisted of different layers, and the slip surfaces of most landslides formed between upper blackish and lower brownish tephra layers. Paudel et al. (2007) evaluated the spatio-temporal patterns of historical shallow landslides in Aso caldera, based on statistical analysis of shallow landslides that occurred between 1953 and 1998. Kasama et al. (2011) recently tried to clarify the factors which led to these geodisasters, based on geo-mechanical and hydro-mechanical evaluation.

One landslide site on Aso caldera was selected for this study to examine the initiation mechanism of the shallow landslides during heavy rainfall. The main objectives of our field investigations were observation of the geological conditions, measurement of the longitudinal profile, and collection of soil samples for laboratory analysis. Laboratory experiments were conducted to determine the physical and mechanical properties of the soils, and soil behavior in response to increase in porewater pressure. Based on the results of our field and laboratory investigations, we propose a probable initiation mechanism for the rainfall-induced shallow landslides on the northeastern rim of Aso caldera.

\section{Study site}

\section{Geological condition}

The study site is located at Ichinomiya (Kumamoto Perfecture) in the northeast of Aso caldera (Fig. 2). Aso caldera extends some $17 \mathrm{~km}$ from east to west, and $25 \mathrm{~km}$ from north to south, with an area of about $350 \mathrm{~km}^{2}$. The central crater group is referred to as Mt. Aso, and incorporates five peaks (Mt. Taka,
Mt. Naka, Mt. Eboshi, Mt. Kishima and Mt. Neko). The caldera was created by four major eruptive events, known as Aso-1, Aso-2, Aso-3 and Aso-4 (Table 1). Huge volumes of basaltic to rhyolitic lavas and pyroclastic fall and flow deposits are distributed around the rim of the caldera (Hunter 1998). The Aso-4 eruption, the latest and largest eruption, produced multiple pyroclastic flows. The pyroclastic flows flowed into valleys and formed pyroclastic-flow plateaus. Eruptions between each of the four major pyroclastic flow units produced numerous tephra ashfall layers (Miyabuchi 2011). At the study site, the geological units present include pyroclastic flow and ash fall deposits derived from the Aso-1, Aso-2, Aso3 and Aso-4 eruptions. Gravels, sands and muds were deposited at the toe of the slope. Extensive air-fall volcanic ash covered the top of the slope at the outside rim of Aso caldera (Fig. 3).

The cross section of Aso caldera shows that the central cones divide the caldera into the Asodani and Nangodani valleys (Figs. 2 and 4). The mountain chain and plains surround the outer rim of the caldera, and extend to the outer side into a gentle terrain overlain by pyroclastic deposits. Most of the rainfall-induced shallow landslides generated in July 2012 occurred on the inner slope of the northern caldera wall. The study site is located on the slope of the caldera wall at an elevation of about $700 \mathrm{~m}$ a.s.l., and has a slope angle of more than $30^{\circ}$ (Fig. 4).

\section{Heavy rainfall}

Due to stagnation of the wet front during the rainy season, torrential rain fell on the northern Kyushu area (Fukuoka, Kumamoto, Oita and Saga Prefectures) from 11 to 14 July, 2012 (Fig. 5). This event was 


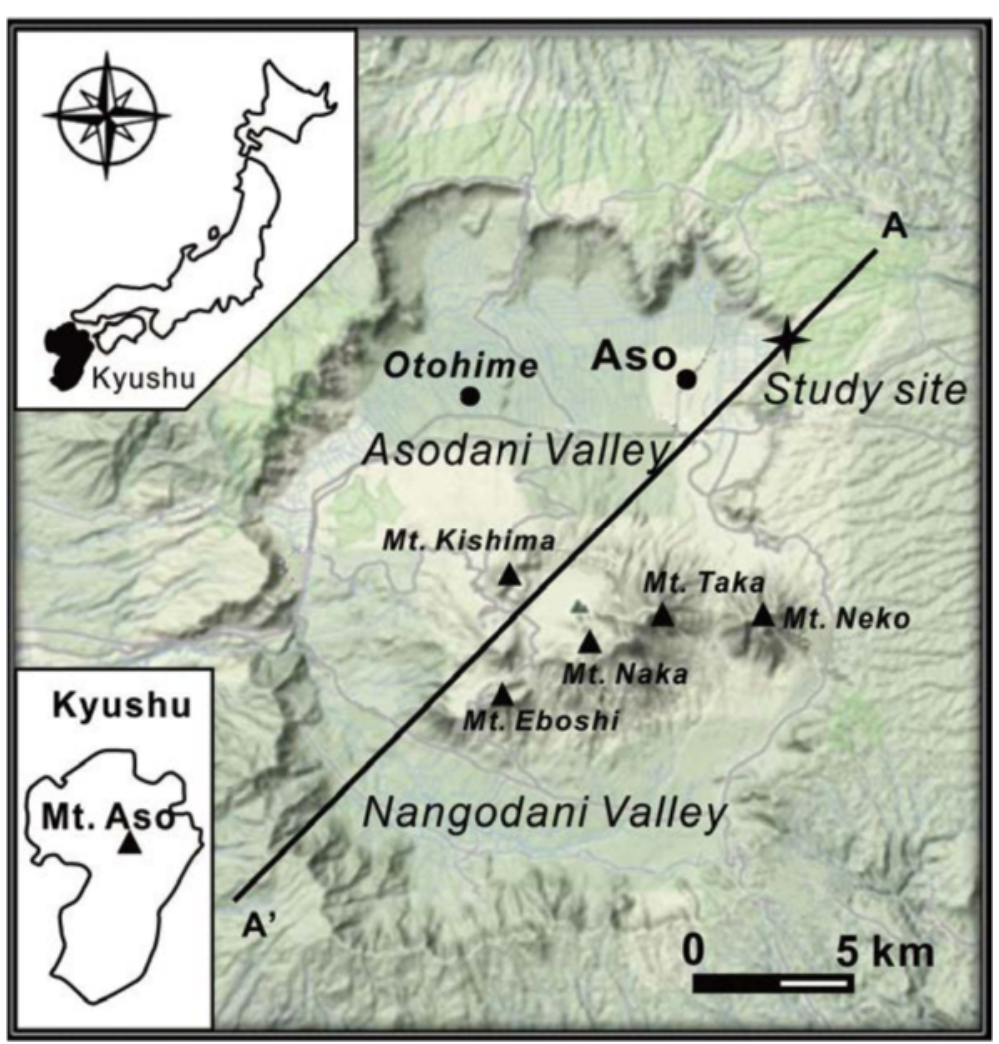

Fig. 2 Location map of the study site (modified from Google Earth)

officially named the 'Northern Kyushu Heavy Rainfall in July 2012' by the Japan Meteorological Agency (JMA). Based on hourly rainfall data collected from all meteorological observatories in Northern Kyushu over the last decade, the maximum hourly rainfall recorded at seven observatories in July 2012 was the highest local rainfall ever recorded in the area. Among these observatories, cumulative rainfall recorded over the four-day period exceeded $500 \mathrm{~mm}$ at five sites, with totals ranging from 570.5 to $816.5 \mathrm{~mm}$ (Table 2).

Most of the shallow landslides occurred on 11 and 12 July, 2012. In order to understand the rainfall characteristics at study site, hourly and cumulative rainfall data for these days was obtained from the rainfall record at the Otohime Meteorological Observatory. The Otohime Meteorological Observatory is located about $10 \mathrm{~km}$ west of the study site (Fig. 2), and is the nearest available record. The rainfall data shows that the maximum hourly rainfall was $108 \mathrm{~mm}$ in the early morning of 12 July, and the cumulative rainfall over the two days was $508 \mathrm{~mm}$ (Fig. 6). This rainfall is the highest recorded at the Otohime Meteorological Observatory over the last decade. Obviously, heavy rainfall was the main triggering factor for this geo-disaster.

\section{Methods}

Field investigation

A representative shallow landslide at Shioi Village in Ichinomiya, Kumamoto Prefecture (Fig. 2) was selected to study the initiation mechanism of shallow landslides on the steep slopes during heavy rainfall. Figure 7 shows the slope after failure. Several shallow landslides occurred in grassland at the rim of Aso caldera (Fig. 8). These shallow landslides were the source of debris flows in the gully. Field investigations were conducted on the

Table 1 Characteristics of the four major eruptive events (Aso-1, Aso-2, Aso-3 and Aso-4) (Aramaki 1984; Hunter 1998)

\begin{tabular}{llll}
\hline Unit & Volume $\left(\mathrm{km}^{3}\right)$ & Eruptive age $(\mathrm{ka})$ & Source and dominant geological units \\
\hline Aso-1 & $>30$ & $370-270$ & Welded tuff \\
Aso-2 & $>25$ & 170 & Welded tuff, in part non-welded deposit of scoria \\
Aso-3 & $>40$ & 100 & Vitric ash, pumice or scoria and welded tuff \\
Aso-4 & $>80$ & 80 & Non-welded deposit of vitric ash fall and pumice \\
\hline
\end{tabular}




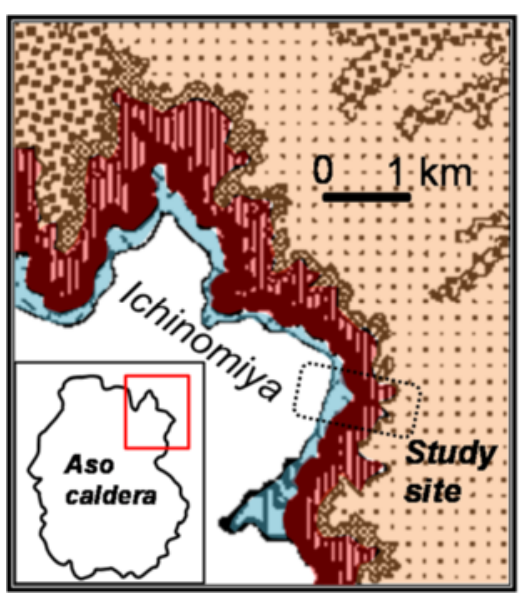

\section{Legend}

\section{Gravel, sand and mud}

Airfall volcanic ash

Aso-4 pyroclastic

flow and ash fall

Aso-3 pyroclastic

flow and ash fall

Aso-2 lava, welded and

nonwelded pyroclastic flow

Aso-1 lava, welded and

nonwelded pyroclastic flow

Fig. 3 Geological map of the study site (after Hunter 1998)

shallow landslide shown in Fig. 8b. Longitudinal profiles were measured to illustrate the terrain of the gully and slope. Soil samples were collected from the main scarp of the shallow landslide for laboratory investigations. Three portable dynamic cone penetration tests were conducted to determine the thickness of the soil layer. In order to measure the hydraulic coefficient of the soil, in-situ infiltration tests were conducted in hand-drilled boreholes of varying depth, above the top of the main scarp of the shallow landslide.

\section{Portable dynamic cone penetration tests}

The test locations are shown in Fig. 8b. During the dynamic cone penetration tests, a $5 \mathrm{~kg}$ hammer was dropped (free fall) from a height of $50 \mathrm{~cm}$. The number of drops $\left(N_{d}\right)$ was recorded for each $10 \mathrm{~cm}$ penetration depth of the cone tip (Qureshi et al. 2009). The thickness of the soil layer and its boundaries could thus be determined, due to the differing strength of the potential sliding bed.

\section{In-situ borehole infiltration tests}

The test locations were located above the main scarp of the shallow landslide, near point A in Fig. 8b. A portable twist drill was used to drill a $0.25 \mathrm{~m}$ deep borehole. A PVC tube was then inserted into the borehole until the bottom was reached. The tube was then filled with water, and the initial water level and start time of water infiltration were noted. The final depth of the water level was measured after a given time interval. A second borehole with a depth of $0.75 \mathrm{~m}$ was drilled near the first borehole (Fig. 9) to determine the variation of soil permeability with increased depth. The same test process was used for the second borehole. Tests were carried out twice in each borehole to obtain an average value. The hydraulic coefficient $(k)$ was calculated using Eq. 1 (Lambe and Whitman 1969);

$$
k=\frac{\pi D}{11 \Delta t} \operatorname{In} \frac{h_{1}}{h_{2}}
$$

where $h_{1}$ and $h_{2}$ are the two consecutive depths of water in meters; $h_{1}$ is the initial depth and $h_{2}$ is the final depth; $D$ is the diameter of pipe, $D=0.1 \mathrm{~m}$; and $\Delta t$ expresses the time interval (in seconds) between the two successive measurements.

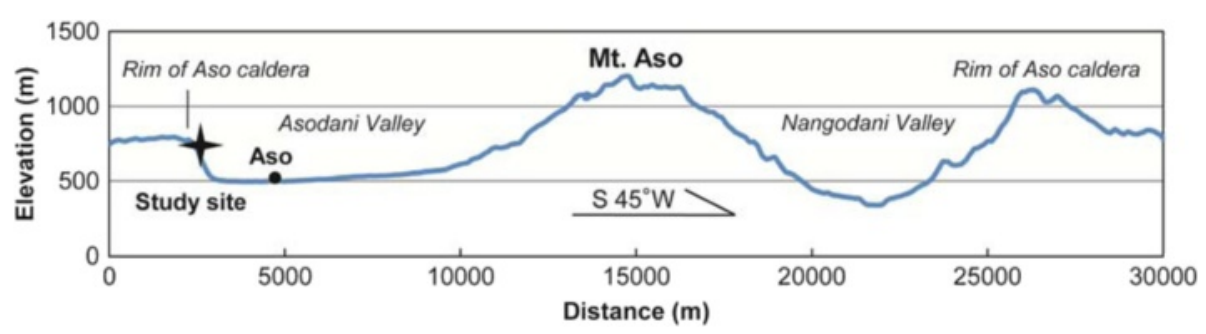

Fig. 4 Cross section of Aso caldera 


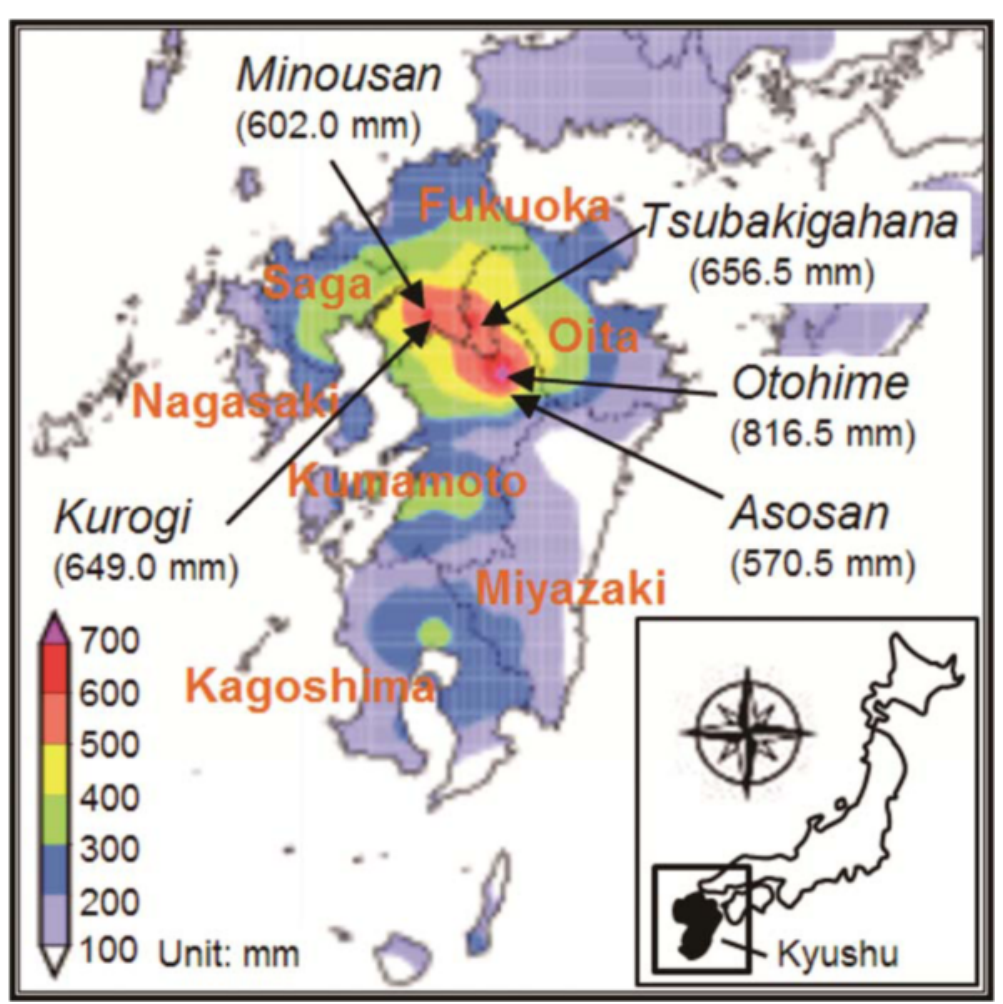

Fig. 5 Cumulative rainfall from 11 to 14 July 2012 (modified from JMA)

\section{Laboratory investigation Physical property tests}

These tests were conducted to determine the physical properties of the soil samples from the shallow landslide. The physical properties determined were the grain size distribution, specific gravity, water content, void ratio, degree of saturation, and unit weight. All tests were performed according to the standards of the Japanese Geotechnical Society (JGS 2010). These parameters are necessary for soil classification and specimen preparation for triaxial tests.

\section{Consolidated-undrained triaxial compression tests}

Consolidated-undrained triaxial compression tests were conducted to determine the effective soil strength. According to the in-situ soil dry density, a given mass of dry soil passing $2 \mathrm{~mm}$ sieving was used to make a cylindrical specimen. In order to get a homogeneous specimen, the dry soil sample was divided into three parts to fill the cylindrical specimen tube with rubber member. After filled the all soil into the specimen tube, the cylindrical surface of each sample was covered by a rubber membrane which is sealed by rubber O-rings on the top and base of the load system. The specimens were then fully saturated. Carbon dioxide $\left(\mathrm{CO}_{2}\right)$ is slowly supplied from the base of the tube to gradually replace the air within the specimen. De-aired water is then supplied to replace and absorb the $\mathrm{CO}_{2}$ and achieve a saturated state. The specimens were confirmed to be fully saturated when the Skempton's B value, which is called the pore-water pressure coefficient (Skempton 1954), was equal or greater than 0.95 (Head 1998). With the fully saturated specimens, three consolidated-undrained triaxial compression tests were then conducted under

Table 2 Daily and cumulative rainfall (more than $500 \mathrm{~mm}$ ) from 11 to 14 July 2012

\begin{tabular}{|c|c|c|c|c|c|c|c|c|}
\hline \multirow[t]{2}{*}{ Rank } & \multirow[t]{2}{*}{ Prefecture } & \multirow[t]{2}{*}{ Municipality } & \multirow{2}{*}{$\begin{array}{l}\text { Meteorological } \\
\text { observatory }\end{array}$} & \multicolumn{5}{|c|}{ Rainfall (mm) } \\
\hline & & & & July 11 & July 12 & July 13 & July 14 & Total \\
\hline 1 & Kumamoto & Aso & Otohime & 15.0 & 493.0 & 148.0 & 160.5 & 816.5 \\
\hline 2 & Oita & Hita & Tsubakigahana & 44.0 & 99.5 & 144.5 & 368.5 & 656.5 \\
\hline 3 & Fukuoka & Yame & Kurogi & 87.5 & 27.0 & 119.5 & 415.0 & 649.0 \\
\hline 4 & Fukuoka & Kurume & Minousan & 115.0 & 23.0 & 232.0 & 232.0 & 602.0 \\
\hline 5 & Kumamoto & Minamiaso & Asosan & 9.5 & 383.5 & 93.5 & 84.0 & 570.5 \\
\hline
\end{tabular}




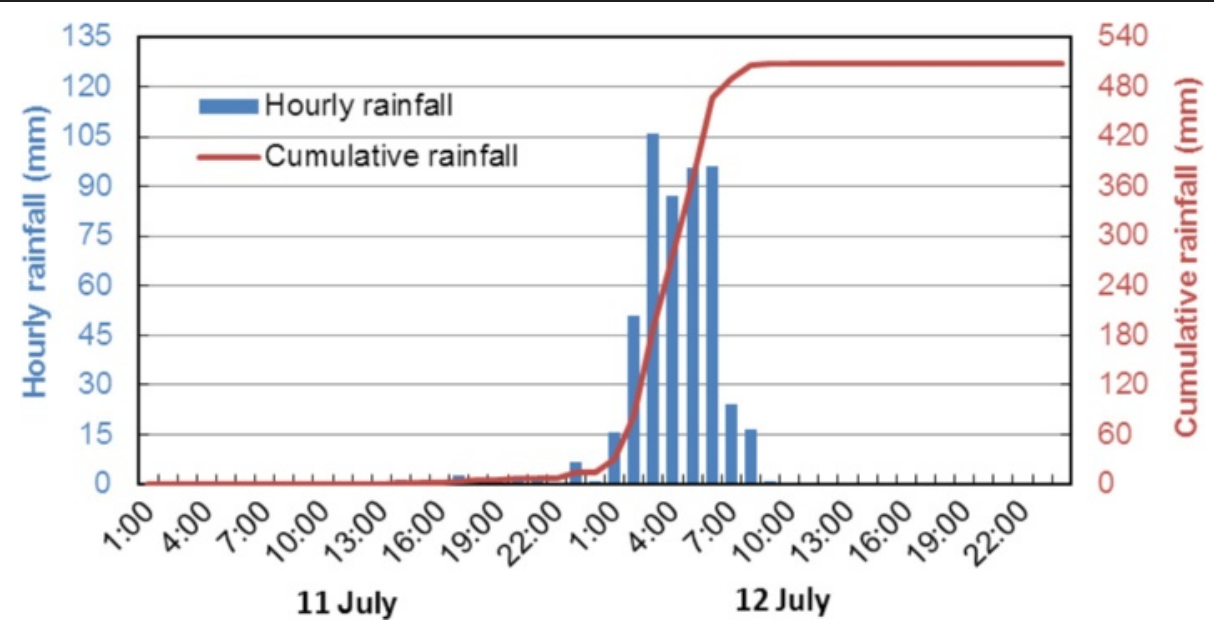

Fig. 6 Hourly and cumulative rainfall at study area on 11 and 12 July, 2012

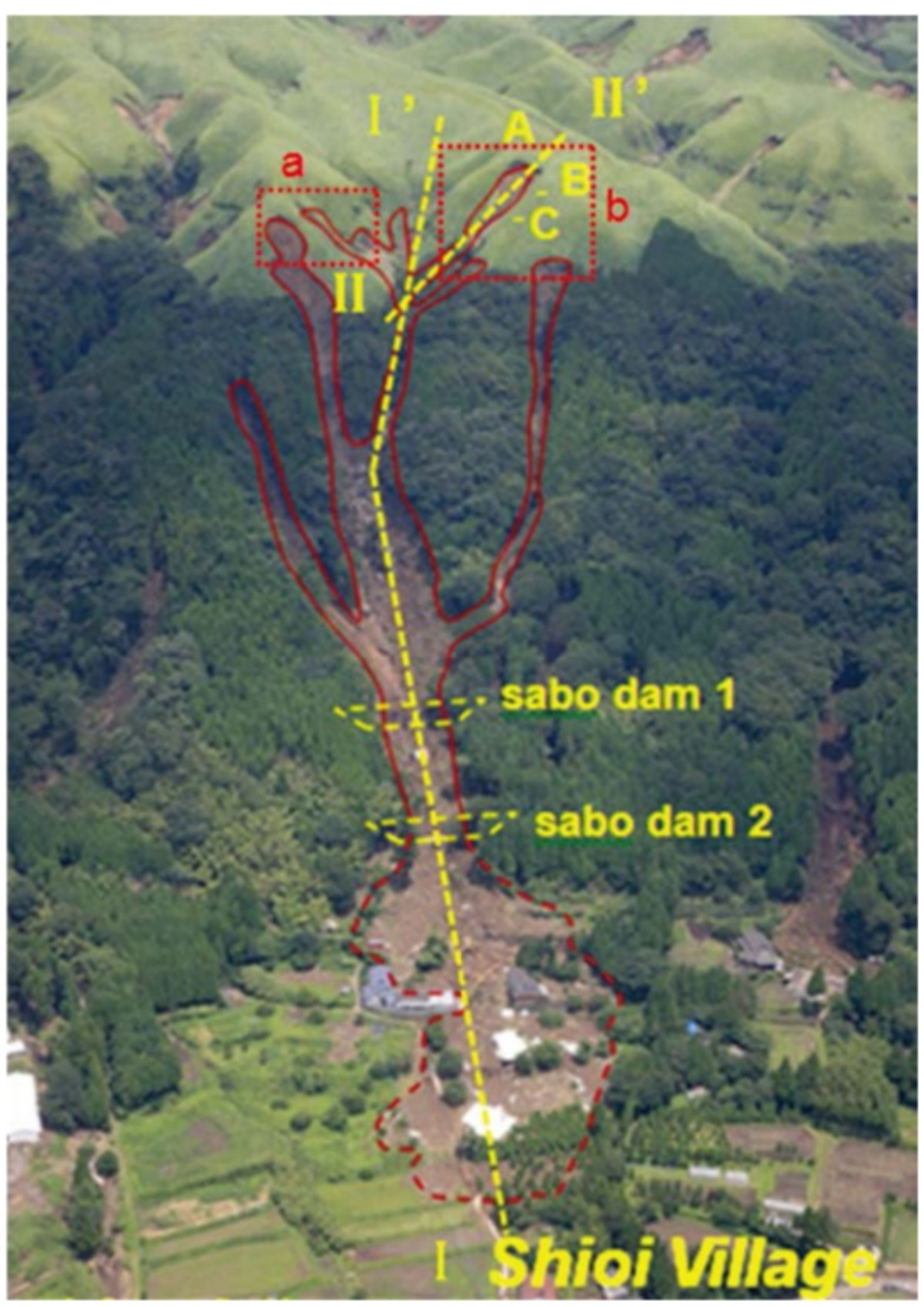

Fig. 7 Photograph of the slope at Shioi Village, Ichinomiya, after failure (image courtesy of Kokusai Kogyo Co., Ltd, Japan) 


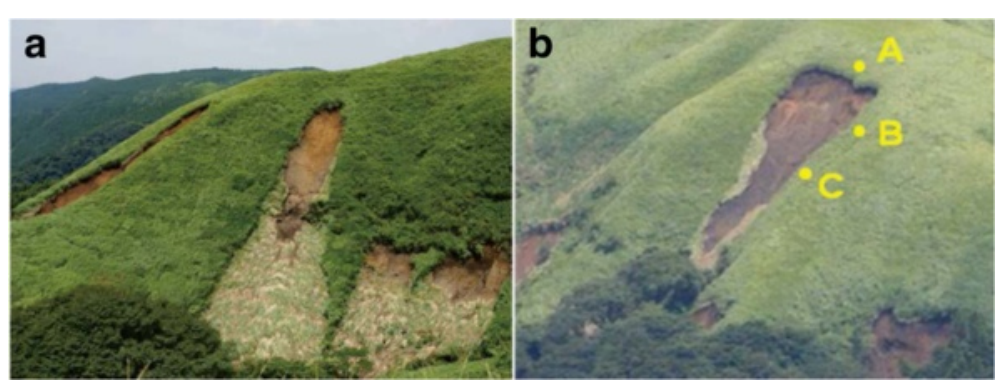

Fig. 8 Shallow landslides in the grassland (locations of (a) and (b) are shown in Fig. 7; Points A, B and C in (b) show the locations of portable dynamic cone penetration tests)

three differing confining stresses $(50,75$ and $100 \mathrm{kPa})$. After normal consolidation, the specimens were compressed at an axial strain of $1.0 \%$ per minute under the undrained condition. Vertical load, pore-water pressure and vertical displacement data was recorded by a data logging system. The shear strength parameters can be obtained from these tests.

\section{Pore-water pressure controlled triaxial test}

A pore-water pressure controlled triaxial test was performed to examine behaviour of the soil with increasing pore-water pressure. The process of specimen preparation and saturation was the same as that for the consolidatedundrained triaxial compression tests. In contrast to the isotropic consolidated-undraind triaxial compression test,

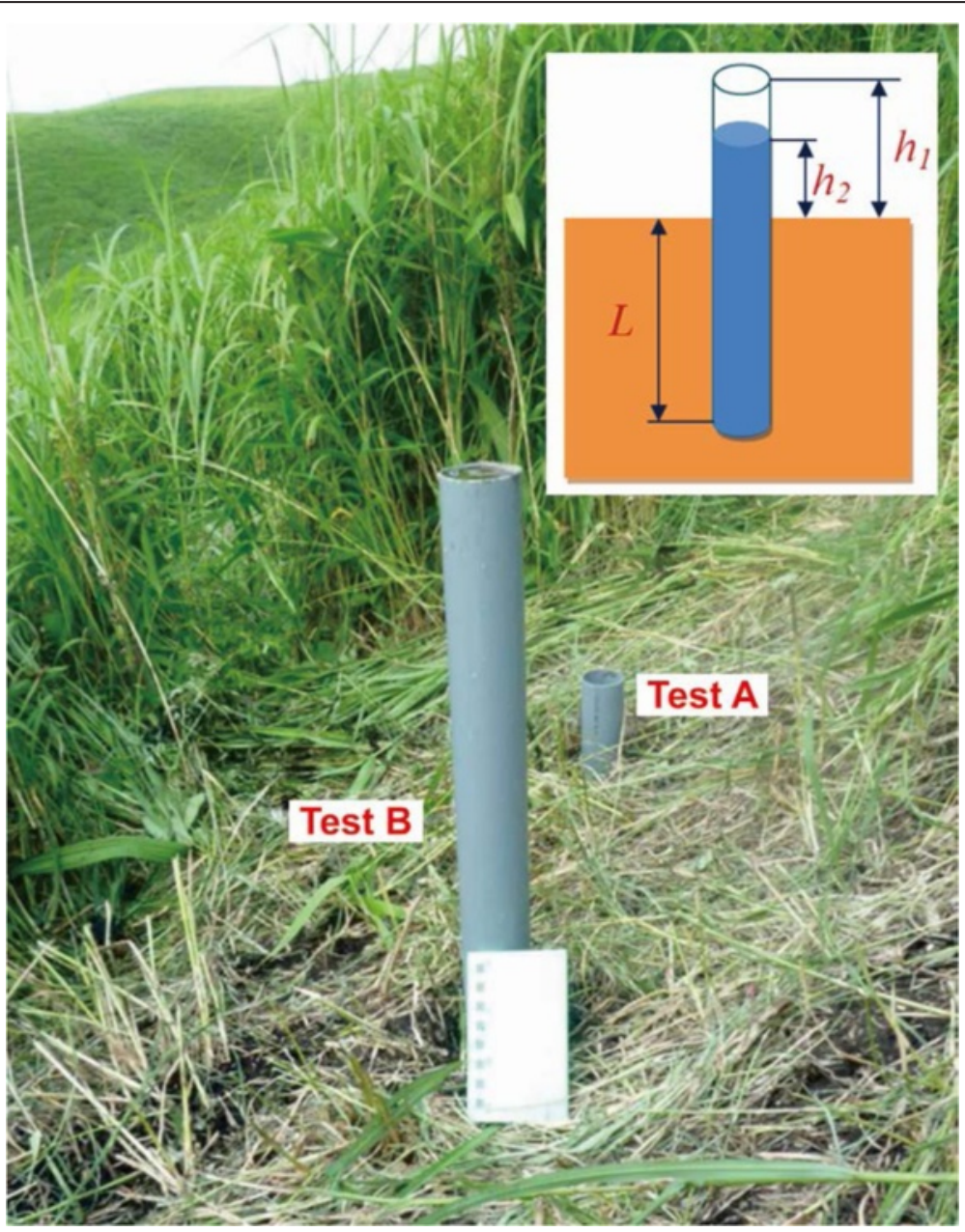

Fig. 9 In-situ infiltration tests 


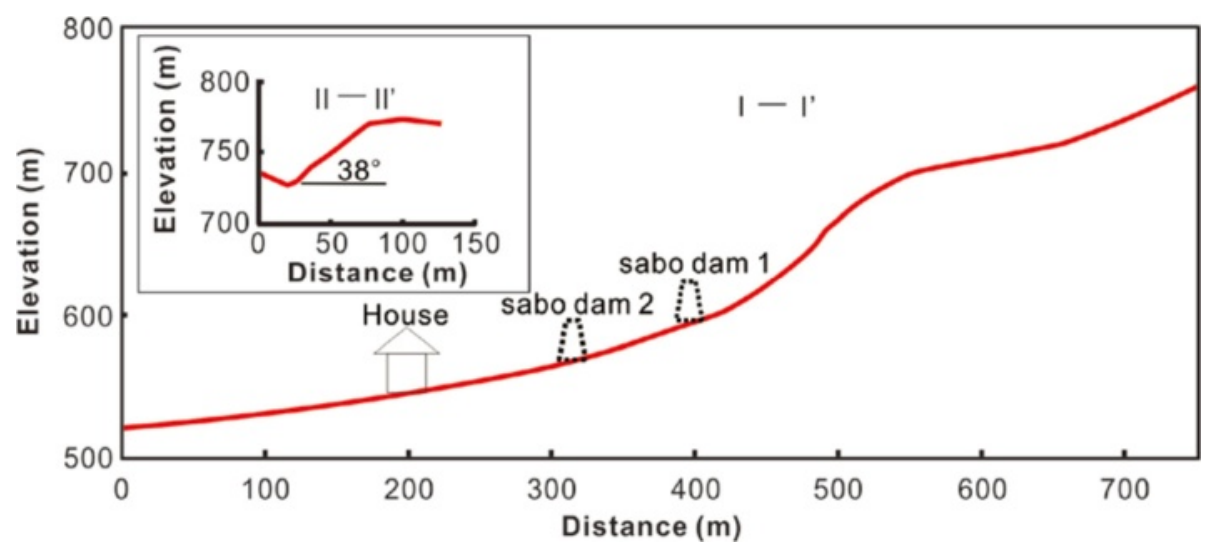

Fig. 10 Longitudinal profiles of the gully and slope

the specimen was consolidated under nonisotropic confining stress. The axial and lateral confining stresses can be obtained according to the vertical and lateral earth pressure. Through this step, the initial stress condition of the soil at the potential sliding zone is simulated. After consolidation, de-aired water is supplied to the specimen by a pore-water pressure controller, to increase the pore-water pressure. The rate of increase in pore-water pressure was $0.2 \mathrm{kPa}$ per minute. Through this step, the effect of porewater pressure accumulation on the potential sliding surface is simulated, and the failure process can be observed.

\section{Results and discussion}

\section{Characteristics of slope and debris flow}

The slopes at the rims of caldera are usually formed by the subsidence of land following volcanic eruptions. Steep gradients are a typical feature of these slopes. According to GIS analysis of the distribution of shallow landslides formed in Ichinomiya during the
July 2012 heavy rainfall event, landslide frequency is greatest at slope angles between 30 and $40^{\circ}$ (Geographical Survey and Photography, Japan 2012). As shown in the longitudinal profiles of the investigated area, the angle of the slope on which shallow landslide occurred is $38^{\circ}$ (I-I' in Fig. 10). A steep slope (II-II' in Fig. 10) is also present behind the sabo dams. The steep terrain will affect both the slope stability and hydrological conditions, such as surface runoff on the slope and seepage in the soil layer. In addition, the steep slope enhances the rapid down-slope movement of debris. Erosion from the debris flows removed the thin soil layer in the gully, leaving bedrock exposed (Fig. 11). The speed of the debris flows increased rapidly as they traveled down the steep slope. The debris flows contained blocks of rock, and destroyed two sabo dams (Fig. 12) and several houses. Finally, debris was deposited on the flat land and paddy fields at the base of the slope.

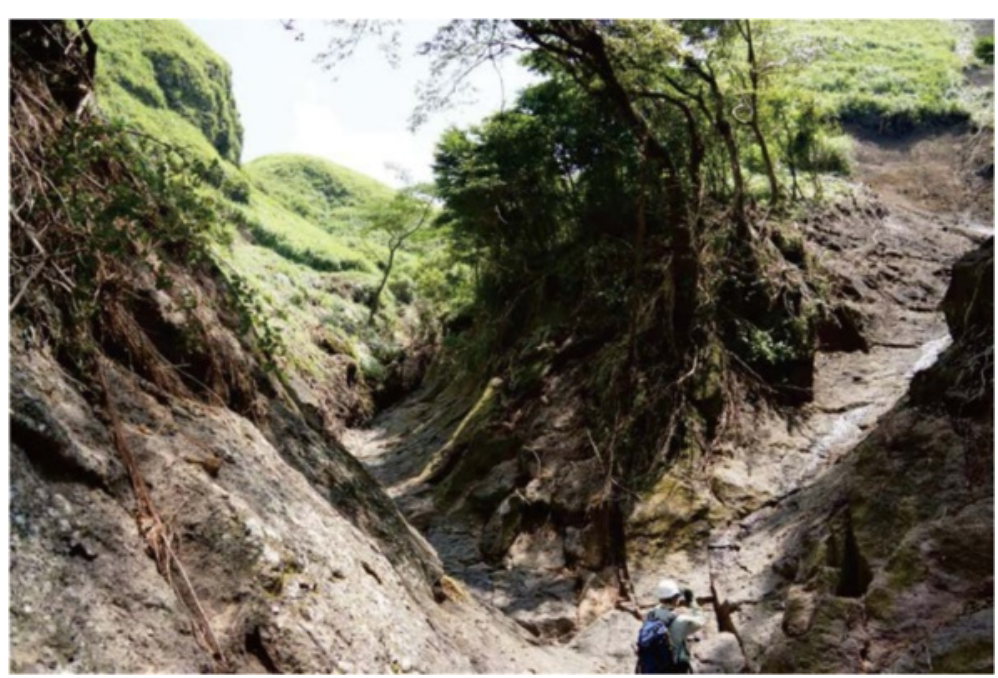

Fig. 11 Exposed bedrock in gullies 


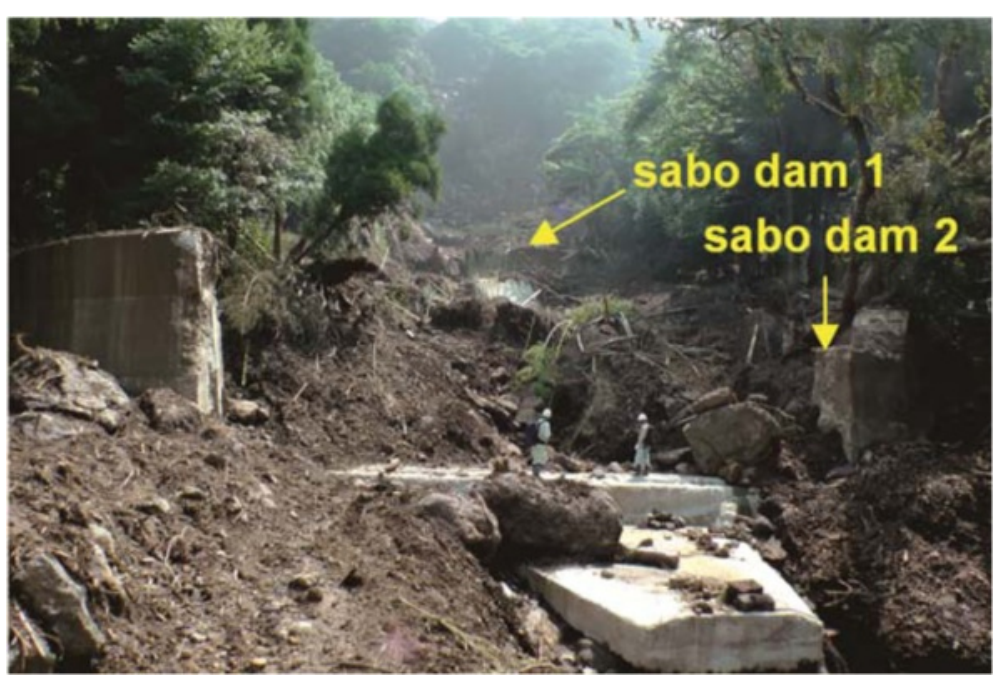

Fig. 12 Sabo dams destroyed by debris flow

The results of the portable dynamic cone penetration tests show that the soil layer is about $3.5 \mathrm{~m}$ thick at the upper slope (Fig. 13). The soil layers gradually become thinner (about $1 \mathrm{~m}$ ) from the upper to the lower slope. In general, soils in the lower parts of hillsides are thicker than in their upper part, due to soil erosion in the upper parts, and deposition in the lower parts. Consequently, the characteristics of the slope at the rim of Aso caldera differ from the general condition. This may be because that erosion on the lower slope is more severe than on the upper slope due to surface run-off during heavy

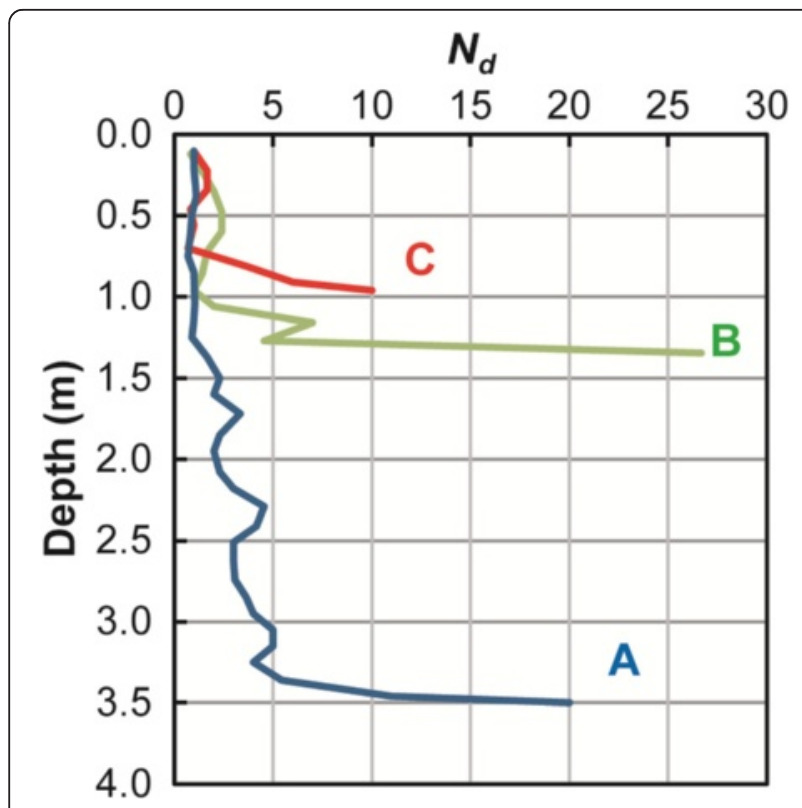

Fig. 13 Results of three portable dynamic cone penetration tests

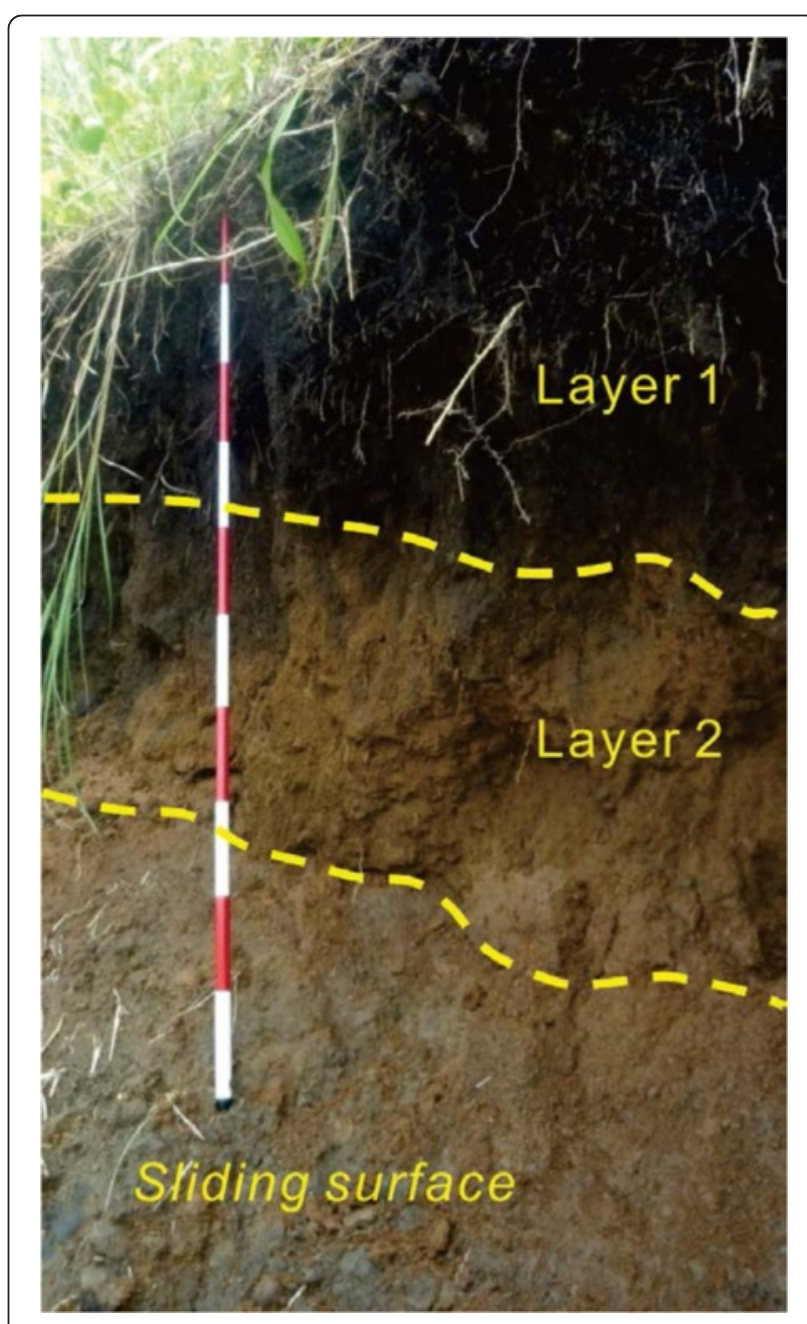

Fig. 14 Main scarp of the shallow landslide 


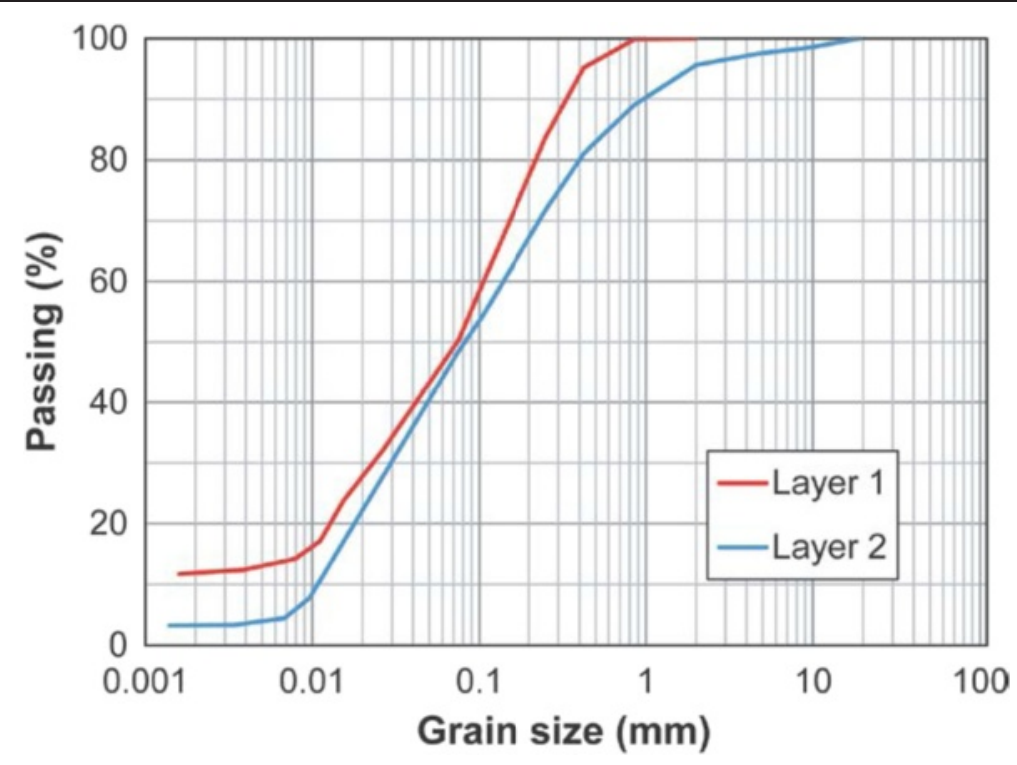

Fig. 15 Grain size distributions of soil samples from different layers

rainfall. Moreover, the slope is quite steep (about $38^{\circ}$ ). Soil eroded from the upper slope will not be deposited in the lower part. Instead, fine soil particles will be deposited in the gully, and this material will transform into debris flows during heavy rainfall.

\section{Physical properties of soils}

The soil in the main scarp of the shallow landslide can be divided into two layers based on the appearance features (Fig. 14). Layer 1, the black uppermost layer, is composed of volcanic ash, humus and plant roots. Coarse sand and gravels occur in the underlying layer 2 . Particle size gradually increases downward, reaching maximum particle diameter of about $20 \mathrm{~mm}$. The sliding zone of the shallow landslide is located at the base of layer 2, which is underlain by a basal gravel layer. Sliding surfaces were observed on the surface of the basal gravel layer. Grain size analysis (sieve and hydrometer analysis) of soil samples from each layer was conducted to determine their grain size distribution (Fig. 15). Fine particles (grain size less than $0.075 \mathrm{~mm}$ ) form around $45 \%$ of the soils in layers 1 and 2. After the occurrence of shallow landslides, on steep slopes these fine materials can easily transform into debris flows during heavy rainfall. According to the Unified Soil Classification System (USCS), layer 1 is composed of poorly graded tephra clay. Layer 2 is composed of clay with coarse sand gravels.

The soil properties of the different layers are shown in Table 3, which summarizes specific gravity, natural water content, void ratio, degree of saturation, total and saturated unit weight. Although, there had been no rainfall for several days before sampling, soil layer 1 maintained a high water content and degree of saturation. This indicates that soil layer 1 has high water retention capability. The unit weight of the topsoil increased about $20 \%$ from natural to saturated condition. These phenomena are related to the properties of soil, such as higher void ratio. High void ratio (5.452) means that soil layer 1 has a loose structure. Internal erosion could easily occur in such a loose soil layer, with high pore-water pressure or seepage.

\section{Rainfall infiltration}

As noted above, heavy rainfall is the main triggering factor for the shallow landslide occurrences at the study site. The results of in-situ infiltration tests are shown in Table 4. Hydraulic conductivity $(k)$ is $1.28 \times 10^{-6} \mathrm{~m} / \mathrm{s}$ at the shallow depth of $0.25 \mathrm{~m}$, compared to $1.90 \times 10^{-7} \mathrm{~m} / \mathrm{s}$ at $0.75 \mathrm{~m}$ depth. The soil at the bottom of the handdrilled boreholes should be compressed and disturbed, and hence the actual hydraulic conductivity should be higher than the experimental value. Nevertheless, these results show that permeability decreases with increase in

Table 3 Physical properties of different soil layers

\begin{tabular}{lll}
\hline Physical properties & Layer 1 & Layer 2 \\
\hline Specific gravity, Gs & 2.271 & 2.734 \\
Water content, $w(\%)$ & 187.0 & 72.0 \\
Void ratio, $e$ & 5.452 & 2.191 \\
Degree of saturation, $S(\%)$ & 78 & 90 \\
Total unit weight, $\gamma\left(\mathrm{kN} / \mathrm{m}^{3}\right)$ & 10.1 & 14.7 \\
Saturated unit weight, $\gamma_{\text {sat }}\left(\mathrm{kN} / \mathrm{m}^{3}\right)$ & 12.0 & 15.4 \\
\hline
\end{tabular}


Table 4 Results of the in-situ permeability tests

\begin{tabular}{llllll}
\hline Parameters & \multicolumn{3}{l}{ Test A } & & \multicolumn{2}{l}{ Test B } \\
\cline { 2 - 3 } \cline { 5 - 6 } & 1 & 2 & & 1 & 2 \\
\hline$h_{1}(\mathrm{~m})$ & 0.15 & 0.15 & & 0.60 & 0.60 \\
$h_{2}(\mathrm{~m})$ & 0.14 & 0.12 & & 0.59 & 0.58 \\
$L(\mathrm{~m})$ & 0.25 & 0.25 & & 0.75 & 0.75 \\
$\Delta t(\mathrm{~s})$ & 1500 & 5100 & & 2700 & 4800 \\
$k(\mathrm{~m} / \mathrm{s})$ & $1.31 \times 10^{-6}$ & $1.25 \times 10^{-6}$ & & $1.78 \times 10^{-7}$ & $2.02 \times 10^{-7}$ \\
Average $k(\mathrm{~m} / \mathrm{s})$ & $1.28 \times 10^{-6}$ & & & $1.90 \times 10^{-7}$ & \\
\hline
\end{tabular}

depth. Paudel et al. (2008) measured the hydraulic conductivity of soils on slope surfaces at ten sites in Aso caldera. They also found that the hydraulic conductivity of soil layer was low, ranging from $1.0 \times 10^{-6} \mathrm{~m} / \mathrm{s}$ to $5.0 \times 10^{-6} \mathrm{~m} / \mathrm{s}$. With the low hydraulic conductivity of the soil layer, during heavy rainfall events most rainfall will transform into surface runoff.

\section{Shear strength of soil}

The stress-strain relationship of the consolidatedundrained tests on the saturated specimens (Fig. 16a) shows that the deviatoric stress increases with the axial strain. The stress-strain curves provide evidence for stress hardening. When the shear strain is over about $13 \%$, the deviatoric stress begins to flatten. For the specimen with high confining pressure $(100 \mathrm{kPa})$, stress softening was observed at the end of the test. Critical state was reached for all three tests with a high axial strain (Fig. 16a).

The relationship between excess pore-water pressure and the axial strain of consolidated-undrained tests on the saturated specimens is shown in Fig. 16b. Positive pore-water pressure was recorded in all three undrained tests. In all soil specimens, pore-water pressure increased to a peak at low strain (about $3 \%$ ), declines

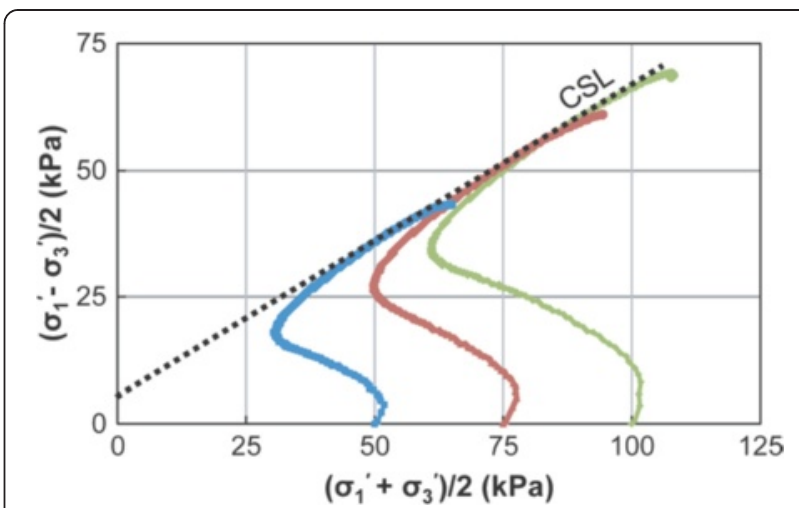

Fig. 17 Effective stress paths under different confining pressures (50, 75 and $100 \mathrm{kPa}$ ). The dotted line indicates the critical state line (CLS)

from its maximum value as the strain increases continuously, and finally reached a minimum value at the end of the tests. The initial buildup of the pore-water pressure suggests that the specimens exhibit contractive behavior. The reduction in the pore-water pressure after the peak indicates that the specimens change from contractive to dilative behavior during shear, as illustrated by the effective stress paths shown in Fig. 17.

All the effective stress paths show a similar trend. Each path moves toward the right initially (increasing $\left(\sigma_{1}^{\prime}+\sigma_{3}^{\prime}\right) / 2$ ), and then moves to the left (decreasing $\left.\left(\sigma_{1}^{\prime}+\sigma_{3}^{\prime}\right) / 2\right)$ until reaching a turning point, after which they turn right, before reaching the critical state line (CSL) at the end of the test. The critical states of saturated specimens can be represented by the CSL in the stress plane. The gradient of the critical state line is 0.6, which corresponds to a critical state line of effective friction of $36.9^{\circ}$ and cohesion of $6.3 \mathrm{kPa}$. In published results of soil shear strength, it was observed that the effective friction angle was about $35^{\circ}$, and cohesion varied between different soil layers (Paudel et al. 2008). The
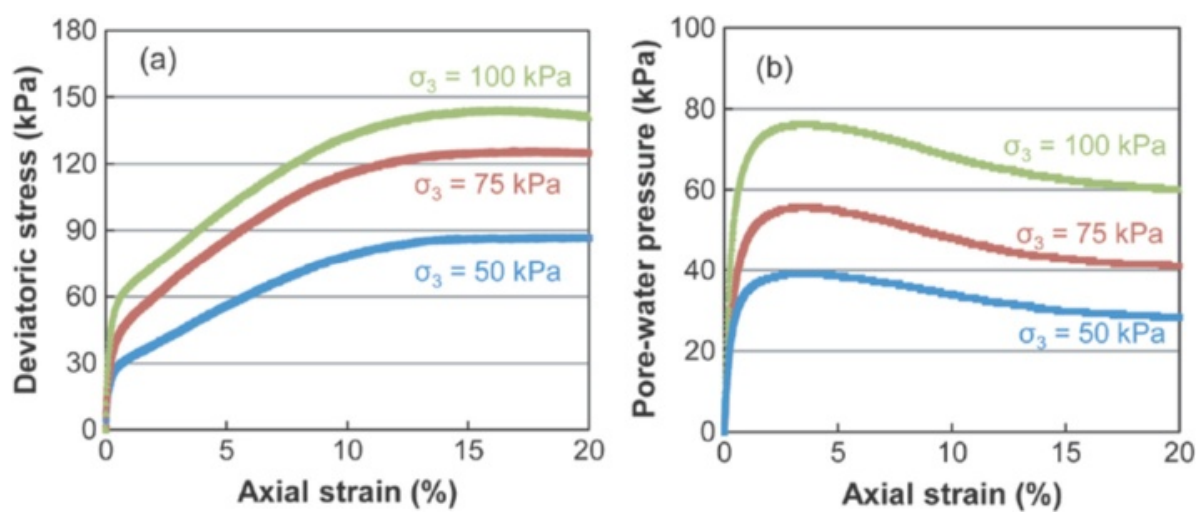

Fig. 16 a Stress-strain relationship; $\mathbf{b}$ relationship between pore-water pressure and axial strain for the consolidated-undrained triaxial compression tests 


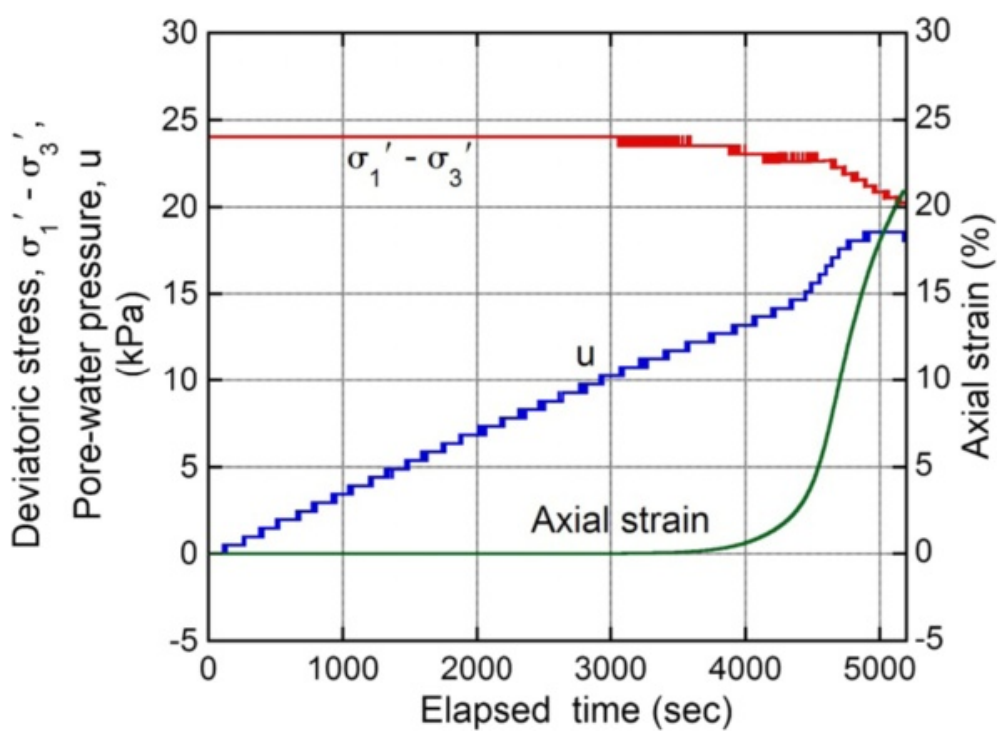

Fig. 18 Relationships between deviatoric stress, axial strain and pore-water pressure for the pore-water pressure controlled triaxial test

high shear strength of these soils explains why the steep slopes on the northeastern rim of Aso caldera are usually stable under normal rainfall during the rainy season.

\section{Soil behavior with the increase in pore-water pressure}

The relationships between deviatoric stress, axial strain and pore-water pressure were obtained through the pore-water pressure controlled triaxial test (Fig. 18). The results show that when the pore-water pressure increased to about $12 \mathrm{kPa}$, the deviatoric stress started to decrease, while the axial strain increased. With the continuous increase of pore-water pressure, the major failure of the soil occurred when the pore-water pressure increased to near $15 \mathrm{kPa}$. At this time, high excess porewater pressure was generated in the soil, causing the obvious decrease of effective stress. In a short time, the axial strain increased rapidly, and exceeded $20 \%$. This soil behavior in response to increase in pore-water pressure can explain the initiation mechanism of the shallow landslides on the slopes. During heavy rainfall, continuous rainfall infiltration can generate a wet front in the soil layer, and in turn forms a saturated zone above the potential sliding surface. The saturated zone will move gradually upwards in relation to the slope surface, and the pore-water pressure acting on the potential sliding surface will increase. Based on the results, it is evident that failure in the soil specimen will not occur, even with high pore-water pressure (less than $12 \mathrm{kPa}$ ). It also means that the slope can maintain stability when the rainfall is not so heavy. However, if the pore-water pressure exceeds the critical value as a result of heavy rainfall, a shallow landslide will be triggered.

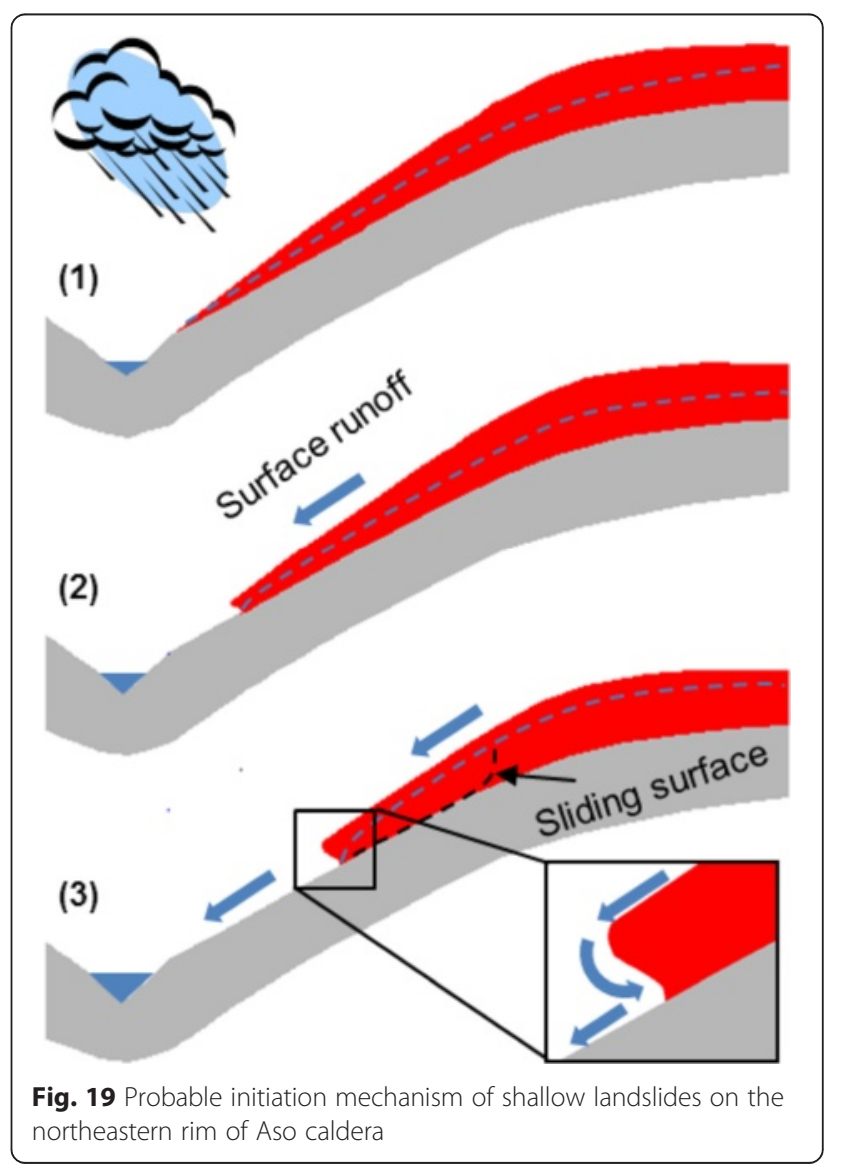




\section{Probable initiation mechanism}

Based on the above discussion of the characteristics of the slope, physical properties of the soil, rainfall infiltration, shear strength of the soil, and soil behavior with the increase in pore-water pressure, a probable initiation mechanism for shallow landslides on steep slopes was developed, as shown in Fig. 19.

(1)During heavy rainfall, surface water infiltrates into the soil layer and generates water level in the slope. The soil layer in the lower part will become fully saturated first because the thickness of the soil layer at the toe of slope is very low.

(2)Due to the limitation imposed by the hydraulic conductivity $(k)$ of the soil, infiltration rate of rainfall is far less than the rainfall intensity. Most of the rainfall transforms into surface runoff. On the steep slope, high-speed surface runoff will remove the toe of the slope.

(3) Gradual headward erosion may occur, and remove the soil layer in the lower part that provides the resistance for slope stability. Meanwhile, the groundwater level in the slope keeps increasing due to the continuous rainfall infiltration, i.e. the porewater pressure in the soil builds up at the potential sliding surface. When the pore-water pressure exceeds the critical value, a shallow landslide will be triggered, as a result of heavy rainfall.

\section{Conclusions}

1. High-intensity rainfall is the main triggering factor for shallow landslides on the northeastern rim of Aso caldera. On these steep slopes, the sliding mass created after the occurrence of shallow landslides transformed into debris flows during heavy rainfall.

2. The soil on the slopes on the northeastern rim of Aso caldera has high shear strength. The soil behavior in response to increase in pore-water pressure shows that failure of the soil will not occur until the porewater pressure exceeds a relatively high value. This explains why such steep slopes can be stable under normal rainfall during the rainy season. However, if the pore-water pressure exceeds the critical value as a result of heavy rainfall, shallow landslides will be triggered.

3. The probable initiation mechanism indicates that the initial failure process of the shallow landslides on the northeastern rim of Aso caldera begins with toe erosion caused by surface runoff. The combination of this loss of resistance force at the toe of the slope and increase of pore-water pressure in the slope during heavy rainfall will finally bring the slope to a critical condition.

\section{Competing interests}

The authors declare that they have no competing interests.

\section{Authors' contributions}

HY, FW, KA and SA paticipated in the field investigations. HY conducted the triaxial tests and drafted the manuscript. FW and HY conducted the portable dynamic cone penetration tests and in-situ infiltration test. W contributed to the sliding mechanism. All authors read and approved the final manuscript.

\section{Acknowledgements}

This work was financially supported by JSPS KAKENHI Grant Number A2424106 for landslide dam failure prediction. Messrs. Mitani and Sonoyama of Shimene University joined the field investigtion. The authors thank Dr. Barry Roser for his helpful and constructive comments on the manuscript. Valuable and constructive comments from anonymous reviewers are also appreciated.

\section{Author details}

'Department of Geoscience, Shimane University, Matsue 690-8504, Japan. ${ }^{2}$ Department of Physical Geography and Geoecology, Charles University in Prague, Prague, Czech Republic. ${ }^{3}$ National Research Institute of Fire and Disaster, Chofu, Tokyo, Japan. ${ }^{4}$ Forestry and Forest Products Research Institute, Tsukuba, Japan.

Received: 5 February 2015 Accepted: 29 July 2015

Published online: 11 August 2015

\section{References}

Aramaki S (1984) Formation of the Aira caldera, southern Kyushu, 22000 years ago. J Geophys Res 89:8485-8501.

Capra L, Lugo-Hubp J, Borselli L (2003) Mass movements in tropical volcanic terrains: the case of Teziutlan (Mexico). Eng Geol 69(3-4):359-379.

Dahal R, Hasegawa S, Nonomura A, Yamanaka M, Masuda T, Nishino K (2009) Failure characteristics of rainfall-induced shallow landslides in granitic terrains of Shikoku Island of Japan. Environ Geol 56:1295-1310.

Dai F, Lee CF (2002) Landslide characteristics and slope instability modeling using GIS, Lantau Island, Hong Kong. Geomorphology 42(3-4):213-228.

Dai F, Lee CF, Wang S (1999) Analysis of rainstorm-induced slide-debris flows on natural terrain of Lantau Island, Hong Kong. Eng Geol 51(4):279-290.

Dai F, Lee CF, Tham LG, Ng KC, Shum WL (2004) Logistic regression modelling of storm-induced shallow landsliding in time and space on natural terrain of Lantau Island, Hong Kong. Bull Eng Geol Environ 63(4):315-327.

Fire and Disaster Management Agency, Japan (2012) Report of heavy rainfall from 11 July 2012. (No. 20). http://www.fdma.go.jp/bn/2012/detail/766.html. Accessed 20 January 2015

Geographical Survey and Photography, Japan (2012) Investigation of debris flows at Mt. Aso caldera triggered by Northern Kyushu heavy rainfall in 2012 using GIS. http://gpi-net.jp/study/aso/aso.html. Accessed 20 January 2015.

Giannecchini R, Galanti Y, Avanzi G (2012) Critical rainfall thresholds for triggering shallow landslides in the Serchio River Valley (Tuscany, Italy). Nat Hazards Earth Syst Sci 12:829-842

Head KH (1998) Manual of soil laboratory testing (Vol. 3). John Wiley \& Sons, New York.

Hunter AG (1998) Intracrustal Controls on the coexistence of tholeiitic and calc-alkaline magma series at Aso Volcano, SW Japan. J Petrol 39(7):1255-1284

Japan Society of Civil Engineering (JSCE) (2013) Investigation report of the disaster caused by Northern Kyushu heavy rainfall in July 2012. http://committees.jsce.or.jp/ report/system/files/1-1-6.pdf. Accessed 20 January 2015.

Kasama K, Jiang Y, Hiro-oka A, Yasufuku N, Sato H (2011) Geo-and hydromechanical evaluation of slope failure induced by torrential rains in northern-Kyushu area, July 2009. Soils Found 51(4):575-589.

Lambe WT, Whitman RV (1969) Soil Mechanics. John Wiley, New York

Maharaj R (1993) Landslide processes and landslide susceptibility analysis from an upland watershed: a case study from St. Andrew, Jamaica, West Indies. Eng Geol 34:53-79.

Matsushi Y, Saito H, Fukuoka H, Furuya G (2013) Landslides of tephra deposits on hillslope of the Aso caldera wall and volcanic central cones by the NorthKyushu heavy rainfall at July 2012. Annuals of Disaster Prevention Research Institute, Kyoto University (No. 56). http://repository.kulib.kyoto-u.ac.jp/ dspace/bitstream/2433/181543/1/a56b0p28.pdf. Accessed 20 January 2015. 
Miyabuchi Y, Sugiyama S (2011) 90,000-year phytolith record from tephra section at the northeastern rim of Aso caldera, Japan. Quat Int 246(1-2):239-246.

Miyabuchi Y, Daimaru H, Komatsu Y (2004) Landslides and lahars triggered by the rainstorm of June 29, 2001, at Aso Volcano, Southwestern Japan. Trans Jpn Geomorphol 25(1):23-43.

Miyabuchi Y, Koji T, Ogawa Y, Shimizu T (2007) Runoff and sediment discharge triggered by the Typhnoon 200514 (Nabi) in forested watersheds, Southern Kyushu, Japan. Trans Jpn Geomorphol 28(2):127-142.

Miyase M (2012) Investigation report of the debris flow caused by heavy rainfall in July 2012. Sabo 112:7-11.

Paudel PP, Moriwaki K, Morita K, Kubota T, Omura H (2003) An assessment of shallow landslides mechanism Induced by rainfall in Hakoishi area. Kyushu Journal of Forest Research 56:122-128.

Paudel PP, Omura H, Kubota T, Inoue T (2007) Spatio-temporal patterns of historical shallow landslides in a volcanic area, Mt. Aso, Japan. Geomorphology 88(1-2):21-33.

Paudel PP, Omura H, Kubota T, Devkota B (2008) Characterization of terrain surface and mechanisms of shallow landsliding in upper Kurokawa watershed, Mt Aso, western Japan. Bull Eng Geol Environ 67(1):87-95.

Qureshi MU, Towhata I, Yamada S, Aziz M, Aoyama S (2009) Geotechnical risk assessment of highly weathered slops using seismic refraction technique. In: Oka F, Murakami A, Kimoto S (eds) Prediction and simulation methods for geohazard mitigation. Taylor \& Francis Group, London.

Skempton AW (1954) The Pore-Pressure Coefficients A and B. Geotechnique 4(4):143-147.

The Japanese Geotechnical Society (JGS) (2010) Soil test: basic and guidance (The second revision). Maruzen press.

Wang F, Wu YH, Yang H, Tanida Y, Kamei A (2015) Preliminary investigation of the 20 August 2014 debris flows triggered by a severe rainstorm in Hiroshima City, Japan. Geoenvironmental Disasters 2:17. doi:10.1186/ s40677-015-0025-6.

Yang H, Wang F, Miyajima M (2015) Investigation of shallow landslides triggered by heavy rainfall during typhoon Wipha (2013), Izu Oshima Island, Japan. Geoenvironmental Disasters 2:15. doi:10.1186/s40677-015-0023-8.

Yu FC, Chen TC, Lin ML, Chen CY, Yu WH (2006) Landslides and rainfall characteristics analysis in Taipei City during the Typhoon Nari event. Nat Hazards 37(1-2):153-167.

Zhu JH, Anderson SA (1998) Determination of shear strength of Hawaiian residual soil subjected to rainfall-induced landslides. Geotechnique 48(1):73-82.

\section{Submit your manuscript to a SpringerOpen ${ }^{\circ}$ journal and benefit from:}

- Convenient online submission

- Rigorous peer review

- Immediate publication on acceptance

- Open access: articles freely available online

- High visibility within the field

- Retaining the copyright to your article

Submit your next manuscript at $>$ springeropen.com 